\title{
Public Expenditures in Syria and its economic effects During the period (2000-2011) (Comparative analysis study)
}

\author{
Dr. Ghassan Farouk Ghandour \\ College of Financial \& Administration-Department of Accounting \& IT, Cihan University/Sulaiymani, \\ Kurdistan Region Government/Iraq.
}

\begin{abstract}
The public Expenditures in Syria affect on macroeconomic variables, the most important GDP growth rates, either directly or indirectly, as public expenditure on private consumption affected by the multiplier, in addition to its impact on the investment directly and indirectly.
\end{abstract}

Key words: public Expenditures - GDP - consumption - investment

\section{Introduction}

It is the public Expenditures of the most important monetary policy tools that can be the government through which increase their gross national product and economic growth. And in order to these expenses to effect a "positive happen in the economy, it must be the policy that sets the general expenditures policy, according to the consequences of these expenses from the effects of and consistent with the desired its creation to achieve political objectives and effects of this so-called some economists," the principle of functional expenses "where public expense become a tool to achieve a particular mission and a means to an end, if negated mission goal of us no longer the wisdom of expenditures government has (Hashish, 1982: p182). for this reason, has been conducting many scientific studies to measure the economic impact of public expenditures on the national economy in order to analyze and evaluate these expenses and thus get a better possibility to draw public expenditures policies in order to achieve their desired goals.

Research objectives

This research aims to formulate public expenditures relationship in Syria with variables total economy in order to be adopted as a basis for policy-making expenditures in particular, and financial policy in general.

Research problem

This research touches to a reform of the financial system, the most important topics related to the process of economic reform in Syria, and public expenditures constitute a great importance as one of the components of the financial system, and given the importance of the subject has been thrown problematic research in the following question:

What is the impact of public expenditure in Syria on GDP? Consumption and private investment? Research hypotheses

1) There is a relationship between the growth rate of public expenditure and the rate of GDP growth.

2) There is a relationship between the growth rate of public expenditure and the rate of consumption growth.

3) There is a relationship between the growth rate of public expenditure and the rate of investment growth.

Research Methodology

1.in this research will be relied on in this research descriptive analytical method which is based on the description and analysis of the characteristics studied, the time period that will be addressed is the study (20002011), noted that this data has just been published to date.

2. As will use the econometric models and the application of some equations and mathematical models to calculate the impact of public expenditure on economic variables.

First: analyzing the impact of public expenditure on GDP

The economic literature and the theory of public finance economics emphasized the role of public expenditure in the impact on GDP and the following is a brief explanation of some of these theories (poddar \& Hunking, p461-462):

The general theory of Keynes: this theory shows that public expenditures is part of total demand, which means that the increase in public expenditures resulting in increased demand for goods and services and with the assumption that the productive apparatus is full flexible because the increase in public expenditures will lead through the so-called multiplier to increase the GDP and raise the utilization rate.

The theory of portfolio: This theory developed by Baumol and Tobin and this theory shows that the impact of public expenditure on GDP depends on the manner in which they are funded, and if the financing of these expenditures from monetary issuance or external borrowing the effect of the multiplier will be greater than if these expenses were financed through taxes or internal borrowing. 
Quantity theory of money: this theory developed by both M. Friedman and Miselman, and this theory confirm, the same was confirmed by portfolio theory that the impact of public expenditure depends on how the funding shall be with expansionary effect on GDP if funded new monetary issuance or from external borrowing.

Before entering into the quantitative analysis of the relationship between public expenditures and economic growth in Syria shows us the review of the evolution of each of the public expenditure and GDP in Syria through Figure 1 consensus noticeable in the time direction of the development of each show during most of the period from 2000 to 2011. However, the compatibility between each of the two indices highlights the dilemma of determining the direction of the causal relationship between each of the public expenditure and GDP through the question about the fact that public expenditures are paid economic growth or the development of the national income is the exact public expenditure by revenue size provided by the budget through taxes and fees.

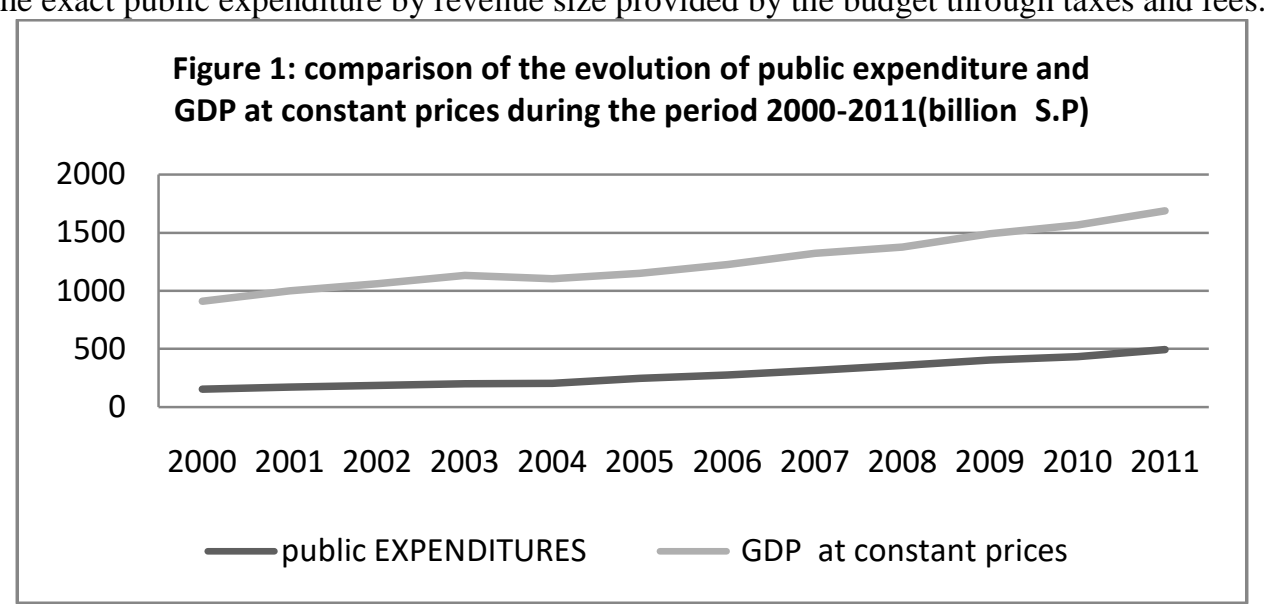

And becomes the determining relationship more difficult in cases depending compatibility from happening and for the simple reason that economic growth is determined by factors other than public expenditures alone also show through the figure that in the last three years of the period decreased public expenditure at constant prices or can say they stopped growing while GDP at constant prices has achieved significant development growth rate of the total exceeds $16 \%$, while public expenditures were only $1.6 \%$ rate evolve. As it can be seen through the same Figure that in the period leading up to 2008, there was a positive correlation between public expenditures and GDP growth at constant prices growth.

And return to discuss the evolution of the proportion of public expenditure in the Syrian economy to the GDP, it can be summarized in the evolution of this ratio by Figure 2 in three stages. The first stage is characterized by steadily proportion of public expenditure to GDP over the period 2000-2004 at a level of more than 26\% and the second stage is characterized by the increase in this ratio between 2005 and 2008 to reach its highest level in 2008 increased by $33.4 \%$ of GDP , while the third stage is characterized by a steady decline until it reached less than $29 \%$ in 2010 and to stabilize at the same percentage in 2011.

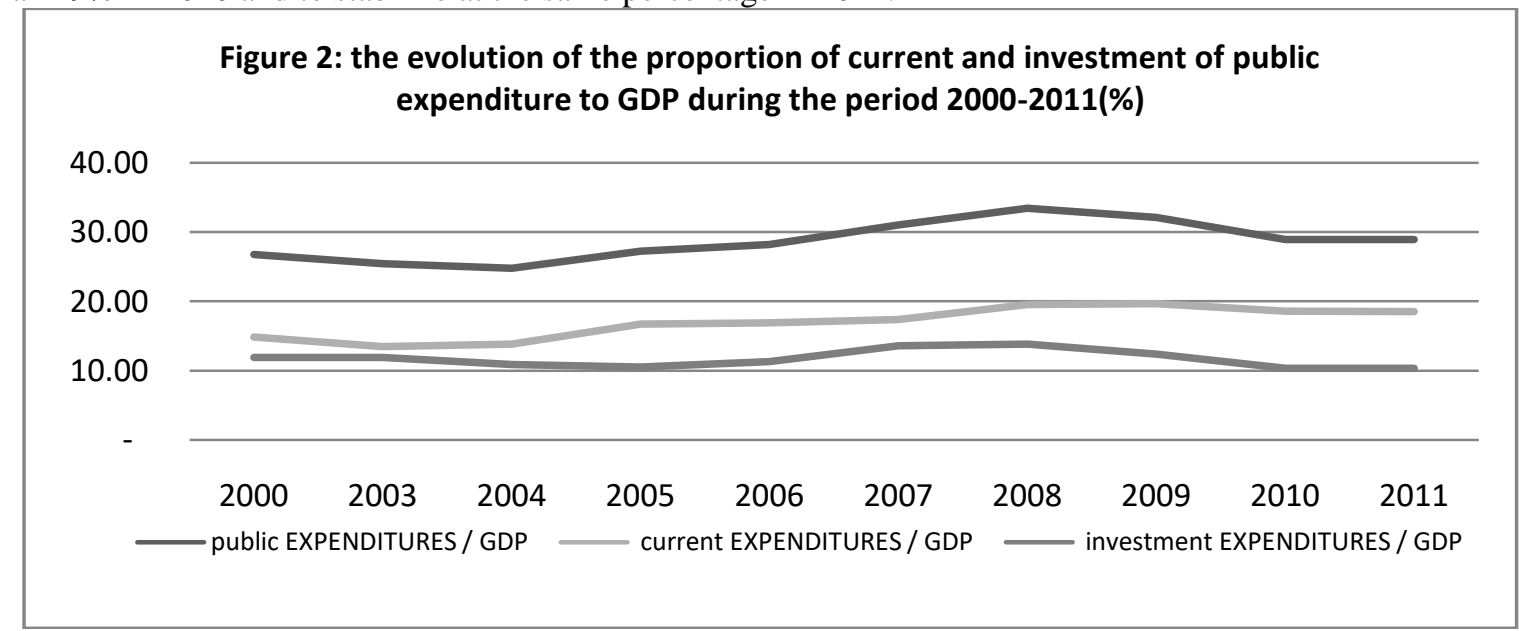

The proportion of public expenditure stability of the GDP during the period 2000-2004 due to the province followed by the financial authority at the time of financial policy as it is because of the scarcity of resources, where carving expenditures trend contractionary policy for fear of having to finance the deficit and falling inflation, which has been installed salaries and wages (Nejmeh, 2003: p12) in addition to the legalization of necessary investment expenditures for public sector companies and is showed by the figure above, where current expenditures and investment has taken the same trend during the period 2000-2004. And with the 
decline in growth rates in the period 2000-2004it was changed oriented deflationary financial policy to turn expansionary since 2006 in order to stimulate economic growth and revitalization of domestic demand through the expansion of public expenditures and begin to increase the salaries and wages of workers in the civilian sector and the military. And it may represent an expansion in the transformation of the surplus of the government budget that has been achieved in 2006 by nearly 17 billion SP to a growing deficit reached almost 59 billion SP in 2011.

\section{Quantification of the impact of public expenditure on GDP:}

To measure quantitatively causality between public expenditure and GDP will assume that the latter is the dependent variable, and that the public Expenditures is one of the independent variables that explained through the use of a standard model analysis through St. Louis Model, which was developed by both Jordam and Anderson (Ackley, 1978: p411). This model is based on the grounds that financial policy and monetary policy are two of the most important policies that affect GDP and takes the form with the following formula:

$$
Y_{t}=\alpha+\beta M_{t}+\gamma F_{t}
$$

Whereas:

$\mathrm{Y}=\mathrm{GDP} \quad \mathrm{M}=$ monetary variable (money supply) $\quad \alpha=$ constant

$\mathrm{F}$ = financial variable (whether public expenditures or revenues or budget deficit).

$\gamma, \beta=$ Coefficients of the model and it show the amount of the impact of monetary and financial variables on the national product.

And perform (regression) in a manner least squares on the form, as mentioned above, based on our data, taking in Syria public Expenditures variable represents financial policy in Syria and the narrow (M1) as a variable representing monetary policy over the period 2000 to 2011 we get the results of appreciation next:

$\begin{array}{llll}Y_{t}= & 178.810 & -0.906 M_{t} & +4.226 F_{t} \\ \text { t-static } & (2.987) & (-1.172) & (3.686) \\ \text { Probability Value } & 0.0153 & 0.272 & 0.005\end{array}$

$$
R^{2}=0.961 \quad \bar{R}^{2}=0.953 \quad \text { F-statistic } 111.779 \quad \text { DW } 1.344
$$

This model shows a strong correlation between public Expenditures independent variable and GDP as the dependent variable, while for the result variable money supply were not consistent with what is theoretically expected, it came as appreciation of the variable cash signal a negative coefficient. Variable coefficient reached 4.226 public expenditures by the trust and identify high coefficient but even so it has had to make several attempts to overcome the moral weakness of the monetary variable we offer loyal following.

Finally, it was used another monetary variable is the M2 money supply, but that did not improve the results of the assessment but deteriorated moral values and statistical probability values of the model. And so maybe there is a need to reconsider the form itself, where it is due to the fact that we in the previous equation we use the equation multi returns, it is possible to face some of the statistical problems related to serial interconnection errors appreciation Serial Correlation and also influenced by the current values in the series the previous values. In fact, the weakness of Durban Watson index (DW), which reached /1.34/ indicates the presence of serial correlation between the estimation errors in the model, and is a problem experienced by the financial governments overall, and back to the fact that the values that take the financial variable or monetary in each period includes what is known as the "memory". Result "memory" for the value of the variable in the current period constitutes a medial values of this variable in previous periods, giving relatively more importance to the value of the variable in the most recent previous periods of its value in the earlier periods (Robert \& Daniel, 1998: p476) causing a correlation serial between the estimate errors in the estimated model and leads to what is known as moving Average. There is another phenomenon known as Auto regressive arises from the fact that the dependent variable takes a value in each period based on the realized value of the previous period, and in other words, the gross domestic product achieved growth in the previous period is a contributing factor in the GDP growth in the current period. In addition, the variables used in the model are facing the problem of multicorrelation among them. This was caused by being possible that the deficit is caused by the expansion of government expenditures through monetary issuance financing, which in turn affects the increase in the money supply. Level achieved in and for this reason has been the inclusion of additional variables in the model represents all of the moving average for the period of time the past one and self-regression for one period of time in the form of access to the better results of the model estimation has become so in the following form:

Where:

$$
Y_{t}=\alpha+\beta M_{t}+\gamma F_{t}+A R(1)+M A(1)
$$

$A R(1)$ : Self- correlation $M A(1)$ : Middle - average (memory) for a period of time prior one. 
Public Expenditures in Syria and its economic effects ...

And conduct assessment process again obtained the following results:

$\begin{array}{lllll}Y_{t}= & +0.732 M_{t} & +2.318 F_{t} & 0.687 \mathrm{AR}(1) & 0.926 \mathrm{MA}(1) \\ \text { t-static } & (2.095) & (5.397) & 2.345 & 5.893 \\ \text { Probability Value } & 0.074 & 0.001 & 0.0515 & 0.001\end{array}$

$$
R^{2}=0.981 \quad \bar{R}^{2}=0.973 \quad \text { DW }=1.713
$$

The new statistical test results for this model Indicates to be $98.1 \%$ of the changes in GDP is attributable to changes in public expenditures and the money supply and what is confirmed by the coefficient of determination $R^{2}=$. Also shows Durbin-Watson (D.W test) lack of self-correlation in the form. The $A R(1)$ and $M A(1)$ it can be interpreted simply as the role of representing the Middle-average and self-regression of the decline in gross domestic product in addition to the role of all the other factors that explain the GDP and non-inclusion in the model.

Economically model shows that financial policy played an important role in stimulating economic growth in Syria are greater than the monetary policy during the period studied, reaching regression coefficient between GDP and public expenditure 2.318 and it means that when public expenditures increase by one Syrian pound, it leads to an increase in the gross domestic product increased by 2,328 Syrian pounds. While the regression coefficient between GDP and money supply indicates that the increase in the money supply increased by one Syrian pounds and one leads to increased GDP by 0.732 Syrian pounds. In short, the regression coefficients show that economic activity affected during the period studied further using the public Expenditures of money supply control and the offer is apparently contrary to the concept that brought him many economic theories. Keynesian theory believes that increasing the quantity of money (money supply) lead to lower interest rates which would result in increased investment and therefore increase the total expenditures, which leads through the multiplier mechanism to GDP growth. As you can see portfolio theory that the interest rate is linking the level of income and money supply as an increase in the money supply leads to lower interest rates, but this decline is not reflected directly on the investment, but that changes in interest rates resulting from the increase in money supply affect the the relative prices of assets for example (Bonds), where the lower interest rates mean higher bond prices and hence the money supply affects investment decisions in these assets (Poddar \& Hunking, p461-462). However, by comparing the economic theory with the reality that prevailed in Syria ,during the period studied in the interpretation of the results of the model estimate the gallery above, we find that the cause of the biggest role of public expenditure in economic growth, which refers to the results of model estimation on Syria does not really feel a difference with the theories mentioned and so the simple reason is the absence of monetary policy is almost entirely in Syria during most of the period studied, where the central bank to have lost its powers in the conduct of monetary policy at a time to keep interest rates have been in it for more than 20 years, while liquidity was administered the financing of the budget deficit public expenditures from the Central bank and through the prior credit plans that were imposed on the public banks -which monopolized banking market until the year 2004, which was the most loans give to public sector companies (Philip, 1998: p47).

\section{The analysis of the impact of public expenditures on consumption}

The public expenditures that affect on consumption by directly and indirectly forms. As we noted employ public sector about a third of operating in the Syrian economy, power and form the volumes of salaries and wages paid by the government a major contributor and direct in private consumption, while other expenditures, especially government procurement consumer and investment from the private sector items constitute the incomes of this sector and thereby contribute to the private consumption indirectly. And to analyze the impact of public expenditure on private consumption are reviewed briefly below the development of public and private consumption expenditures indicators in Syria during the period 2000-2011 and then move on to the relationship between public expenditures and private consumption analysis quantified.

The evolution of the final volume of consumption expenditures in the Syrian economy of 455 billion SP in 2000 to 1346 billion SYP in 2011, accounting for a rate of 78\% and an average of GDP during the period. And after it was consumption growth rate has reached $25.5 \%$ in 2001, this growth in the following years fell for it, and until 2008 to reach about 5\% a year and then began to accelerate later in the year 2009,2010 and 2011 and for the right growth rates reached $28 \% 19 \%$ and $12 \%$ respectively. in this way a reflection of the growth of private consumption, which reached at $84 \%$ and $65.6 \%$ average of the GDP during the period, while government consumption reached at $16.2 \%$ and $12.6 \%$ average of the GDP during the period 2000-2011 (see Table 1). 
Public Expenditures in Syria and its economic effects ...

Table 1: GDP and expenditures for the years 2000 to 2011 (at current prices, billion Syrian pounds)

\begin{tabular}{|c|c|c|c|c|c|c|c|c|c|}
\hline \multirow[t]{2}{*}{ Years } & \multicolumn{3}{|c|}{$\begin{array}{l}\text { total expenditures on } \\
\text { consumption }\end{array}$} & \multicolumn{3}{|c|}{ Private final consumption expenditure } & \multicolumn{3}{|c|}{$\begin{array}{l}\text { Government final consumption } \\
\text { expenditure }\end{array}$} \\
\hline & $\begin{array}{l}\% \text { of } \\
\text { GDP }\end{array}$ & $\begin{array}{l}\text { Growt } \\
\text { h rate }\end{array}$ & $\begin{array}{l}\text { Billion } \\
\text { Syrian } \\
\text { pound }\end{array}$ & $\begin{array}{l}\% \text { of } \\
\text { GDP }\end{array}$ & $\begin{array}{c}\% \text { of total } \\
\text { expenditure } \\
\text { on } \\
\text { consumptio } \\
n\end{array}$ & $\begin{array}{l}\text { Growt } \\
\text { h rate }\end{array}$ & $\begin{array}{l}\% \text { of } \\
\text { GDP }\end{array}$ & $\begin{array}{c}\% \text { of total } \\
\text { expenditur } \\
\text { e on } \\
\text { consumpti } \\
\text { on }\end{array}$ & $\begin{array}{l}\text { Growth } \\
\text { rate }\end{array}$ \\
\hline 2000 & $79.7 \%$ & & 454.9 & $66.2 \%$ & $83.1 \%$ & & $13.4 \%$ & $16.9 \%$ & \\
\hline 2001 & $82.7 \%$ & $25.5 \%$ & 571.0 & $70.9 \%$ & $85.8 \%$ & $29.5 \%$ & $11.8 \%$ & $14.2 \%$ & $6.0 \%$ \\
\hline 2002 & $80.5 \%$ & $5.1 \%$ & 600.4 & $69.1 \%$ & $85.8 \%$ & $5.2 \%$ & $11.4 \%$ & $14.2 \%$ & $4.5 \%$ \\
\hline 2003 & $79.8 \%$ & $5.1 \%$ & 630.9 & $68.6 \%$ & $86.0 \%$ & $5.2 \%$ & $11.2 \%$ & $14.0 \%$ & $4.1 \%$ \\
\hline 2004 & $80.9 \%$ & $5.0 \%$ & 662.7 & $70.3 \%$ & $86.9 \%$ & $6.2 \%$ & $10.6 \%$ & $13.1 \%$ & $-1.9 \%$ \\
\hline 2005 & $75.8 \%$ & $3.4 \%$ & 685.0 & $63.4 \%$ & $83.6 \%$ & $-0.5 \%$ & $12.4 \%$ & $16.4 \%$ & $29.2 \%$ \\
\hline 2006 & $73.3 \%$ & $4.2 \%$ & 713.5 & $60.8 \%$ & $82.9 \%$ & $3.3 \%$ & $12.5 \%$ & $17.1 \%$ & $8.4 \%$ \\
\hline 2007 & $71.8 \%$ & $2.3 \%$ & 730.0 & $59.5 \%$ & $82.9 \%$ & $2.3 \%$ & $12.3 \%$ & $17.1 \%$ & $2.5 \%$ \\
\hline 2008 & $73.8 \%$ & $7.9 \%$ & 787.7 & $60.3 \%$ & $81.7 \%$ & $6.3 \%$ & $13.5 \%$ & $18.3 \%$ & $15.5 \%$ \\
\hline 2009 & $79.7 \%$ & $28.0 \%$ & $\begin{array}{c}1,007 \\
9\end{array}$ & $64.0 \%$ & $80.4 \%$ & $25.9 \%$ & $15.6 \%$ & $19.6 \%$ & $37.4 \%$ \\
\hline 2010 & $80.6 \%$ & $19.0 \%$ & $\begin{array}{c}1,199 \\
7\end{array}$ & $66.7 \%$ & $82.8 \%$ & $22.6 \%$ & $13.9 \%$ & $17.2 \%$ & $4.4 \%$ \\
\hline 2011 & $78.9 \%$ & $12.2 \%$ & $\begin{array}{c}1,346 \\
2 \\
\end{array}$ & $66.1 \%$ & $83.7 \%$ & $13.5 \%$ & $12.8 \%$ & $16.3 \%$ & $5.9 \% \mathrm{~V}$ \\
\hline
\end{tabular}

Reference: The Statistic Brochures of years 2000-2011

Quantification of the impact of public expenditures on consumption:

Some Models that quantitatively estimated the impact of public expenditures on private consumption (Cereau, 1982: p351-357) Baily Model, which refers to that private consumption is a function of several variables, including availability income and government expenditures, it also takes into account consumer habits, it is reasonable that the consumption of the current period depends on the level of consumption in the last period, and thus takes the form with the following formula:

$$
C_{t}^{p}=\alpha+\beta_{1} C^{p}{ }_{t-1}+\beta_{2}(Y-T-E)+\beta_{3} E
$$

Where:

$$
\begin{aligned}
& C^{p}: \text { Consumption expenditures } \quad C_{t-1}^{p}: \text { Private consumption in the previous period } \\
& Y-T: \text { Availability income } \quad E: \text { Government expenditures and Consumption } \\
& (Y-T-E): \text { Availability income minus total public expenditure (investment + Consumption) } \\
& \alpha: \text { Constant } \quad \beta_{1}, \beta_{2}, \beta_{3}: \text { Model coefficients }
\end{aligned}
$$

And above estimation model on the Syrian economy data during the 2000-2011 period studied, we see that it did not give the expected results in terms of government expenditures that coefficient was very small with a Probability Value Because this parameter is equal to zero for a very big reached $(0.959)$. The same also for consumption in the previous period as well as for constant which came negative. In addition to that, the Durbin Watson test (D.W) indicates a correlation between self-estimation errors.

$\begin{array}{lllll}C_{t}^{p} & -55.927 & -0.084 C_{t-1}^{p} & 1.164106(Y-T-E) & 0.009 E \\ \text { t-static } & (-1.998) & (-0.511) & (7.214) & (0.053) \\ \text { Probability value } & 0.086 & 0.625 & 0.000 & 0.959 \\ R^{2}=0.993 & \bar{R}^{2}=0.990 & \text { F statistic 326.812 } & \text { DW } 1.216\end{array}$

This Model seems logical in your esteem moral coefficient of income, as well as for the existence of a constant value for the consumer but it is on the one hand refers to the lack of moral appreciation coefficient for consumption in the previous period, which excludes the impact of consumer habits in determining the pattern of consumption. Finally, this model do not appear any moral to private coefficient government expenditures and therefore the estimate mentioned model was unable to diagnose the private and government consumption expenditures relationship.

III. The analysis of the impact of public expenditure on investment 
Investment rose in the Syrian economy from $26.8 \%$ of GDP in 2000 to reach $28.2 \%$ in 2006 and $33.4 \%$ in 2008 , but it declined thereafter to $28.9 \%$ of GDP in 2011 (see Table 2). As we see in figure mentioned, the decline in investment rates in the Syrian economy during the period 2000-2004 due to the recession that prevailed at the time, which we will try to bring the causes of our current discussion in the gallery.

As for the role of both the public and private sectors to invest, we see that the private sector's share fell from $56.2 \%$ of total investment in $2000,12.5 \%$ of the GDP to reach its lowest level in 2006, 35\% of the total investment, 6.6\% of GDP, but it returned and rose until it reached in 2011 to $50 \%$ of the total investment at $13.8 \%$ of GDP. In contrast, the percentage of public investment to GDP continuously increased from $9.7 \%$ in 2000 to reach its highest level in 2003 increased by $14.5 \%$, but declined slightly thereafter to $12.5 \%$ in 2009 to come back and go up again, and up to $13.8 \%$ in 2011.

Table 2. The Evolution of investment in the Syrian economy to GDP During the period 2000-2011

\begin{tabular}{|c|c|c|c|c|c|c|}
\hline \multirow[b]{2}{*}{ Years } & \multirow[b]{2}{*}{ Public expenditure / GDP \% } & \multirow{2}{*}{$\begin{array}{c}\text { Total investment } \\
\text { Of GDP } \%\end{array}$} & \multicolumn{2}{|c|}{ public investment } & \multicolumn{2}{|c|}{ Private investment } \\
\hline & & & $\begin{array}{c}\text { Of total } \\
\%\end{array}$ & $\begin{array}{c}\text { Of GDP } \\
\%\end{array}$ & $\begin{array}{c}\text { Of total } \\
\%\end{array}$ & Of GDP \% \\
\hline 2000 & $\% 26.8$ & $\% 22.2$ & $\% 43.8$ & $\% 9.7$ & $\% 56.2$ & $\% 12.5$ \\
\hline 2001 & $\% 24.5$ & $\% 20.1$ & $\% 47.7$ & $\% 9.6$ & $\% 52.3$ & $\% 10.5$ \\
\hline 2002 & $\% 25.0$ & $\% 18.2$ & $\% 58.0$ & $\% 10.6$ & $\% 42.0$ & $\% 7.7$ \\
\hline 2003 & $\% 25.4$ & $\% 17.6$ & $\% 58.7$ & $\% 10.3$ & $\% 41.3$ & $\% 7.3$ \\
\hline 2004 & $\% 24.8$ & $\% 17.8$ & $\% 59.5$ & $\% 10.6$ & $\% 40.5$ & $\% 7.2$ \\
\hline 2005 & $\% 27.2$ & $\% 17.3$ & $\% 63.6$ & $\% 11.0$ & $\% 36.4$ & $\% 6.3$ \\
\hline 2006 & $\% 28.2$ & $\% 18.7$ & $\% 65.0$ & $\% 12.2$ & $\% 35.0$ & $\% 6.6$ \\
\hline 2007 & $\% 31.0$ & $\% 19.5$ & $\% 61.7$ & $\% 12.0$ & $\% 38.3$ & $\% 7.5$ \\
\hline 2008 & $\% 33.4$ & $\% 23.1$ & $\% 62.6$ & $\% 14.5$ & $\% 37.4$ & $\% 8.6$ \\
\hline 2009 & $\% 32.0$ & $\% 25.9$ & $\% 48.2$ & $\% 12.5$ & $\% 51.8$ & $\% 13.4$ \\
\hline 2010 & $\% 29.0$ & $\% 27.3$ & $\% 47.4$ & $\% 12.9$ & $\% 52.6$ & $\% 14.4$ \\
\hline 2011 & $\% 28.9$ & $\% 27.7$ & $\% 50.0$ & $\% 13.8$ & $\% 50.0$ & $\% 13.8$ \\
\hline
\end{tabular}

Reference: (Ratios) depend on The Statistic Brochures of years 2000-2011

Quantification of the impact of public expenditure on investment

To estimate quantitatively the relationship between public expenditures and private investment in Syria during the period studied was the adoption of the form below and which makes your investment in any period is determined by the private consumption in the previous period, as well as net transfers from abroad, as well as public investment expenditures in the following form:

$$
I_{t}^{p}=\alpha+\beta_{1} C_{t-1}^{p}+\beta_{2} T_{t}+\beta_{3} I_{t}^{g}
$$

Where:

$I_{t}^{p}$ : Private investment

$C_{t-1}^{p}$ : Private consumption in the previous year

$T_{t}:$ Net transfers from abroad

$I_{t}^{g}:$ Public investment expenditures

$\alpha$ : Constant

$\beta_{1}, \beta_{2}, \beta_{3}$ : Model coefficients

And justify the adoption of private consumption in the previous period as an independent variable as a key indicator to make investment decisions for producers as most of the investments made are in the area of manufacturing that is geared for consumption directly and therefore, private consumption is important for feasibility studies for private investments indicator. As for net transfers from the abroad, they are in fact the most important source of private capital, and that is geared to invest in Syria as a result of the weakness on locally and twice the energy savings of the Syrian economy in general. Finally, it is expected that investment expenditures plays an important role in respect of private investment as public investment in infrastructure, improve the investment environment and attract private investment.

And grade mentioned above form through the Syrian governments during the period 2000-2011 we got the following results:

$\begin{array}{lllll}I_{t}^{p} & -29.089 & 0.265 C_{t-1}^{p} & 9.942 T_{t} & -1.386 I_{t}^{g} \\ \text { t-static } & (-2.525) & (8.669) & (6.398) & (-7.311) \\ \text { Probability value } & 0.0395 & 0.000 & 0.000 & 0.000 \\ R^{2}=0.948 & \bar{R}^{2}=0.926 & \text { F statistic 42.865 } & \text { DW 2.077 }\end{array}$


Results indicate that there is a strong relationship between private investment as the dependent variable and both private consumption and net transfers from the abroad and the government's investment as independent variables reaching the correlation coefficient (R) $94.8 \%$ reached the coefficient of determination $\left(R^{2}=\right.$ ) reached at $92.6 \%$ and is referring to that $92.6 \%$ of the changes in private investment can be explained by changes in investment expenditures of previous years and changes in public investment expenditures and changes in net transfers from abroad. And the fact that the various statistical tests confirm morale and the quality of the model estimate, we can say that the economic explanation for this model means that the increase rate of the one Syrian pound and the one leading to increased private investment by 0.265 one Syrian pound private consumer expenditures and each additional pounds of remittances contribute to raising private investment increased by 9.9 Syrian pound.

As for the coefficient estimate for government investment should stop with him, where he was a bit negative signal may seem surprising at first glance, it would be to spend public investment that contributes to the decline in private investment? The answer is simply yes, in terms of government expenditures plays a dual role for the private investments. On the one hand, public investment expenditures lead to the development of infrastructure to improve the investment environment which encourages the private sector to invest and thus raise the private investment rate. But, on the other hand, government expenditures can crowd out private investment in two ways. The first way is when it is the government's deficit through domestic borrowing financing, which reduces the resources available for private investment, and the second way happens when public investment expenditures heading into productive activity directly so it crowds out private investment and occupy positions in the market or get it out of them.

On the other hand, the weakness of the relationship between public expenditure and between the private and other factors, investment decline the efficiency of public expenditures and an impaired ability to accounting may come back as entrusted with the devices keep track of public expenditures bother session documentary and safety and legal paperwork to spend more than its interest in assessing the return economic and social expenditures which does not give a qualitative assessment of performance indicators appropriate importance in the allocation of public expenditures. In this area, some studies indicate that in the habit government expenditures leads to physical infrastructure to increase the productivity of investment and GDP growth (Carlstorm \& Timothy, 1999: p4). But he in case there was a weak correlation between expenditures on infrastructure and GDP growth, it is this due to that not every investment expenditures on infrastructure has value equally building a system of drainage in the city may increase the growth, but the construction of three systems may reduce it as it leads to the misallocation of resources (Philip, 1998: p47).

And the relationship between public expenditures and private investment analysis exhibition must be pointed out that during the period 2000-2004 was followed a series of public actions aimed at reducing overall demand and rehabilitation of the size of the economy in preparation to enter the stage of economic reform (Raj, 2006). These measures have had an active role to the demand and to create a structural imbalance has led to economic recession. These policies have reflected a halt investment in the replacement and renewal in the public sector have also been installed salaries and wages of workers in the public sector as well as to follow the financial policy manifested itself in other areas down the government deficit and a surplus in 2006 (Kannan, 2002). And it has demonstrated the results of this austerity policy down the rate of return on investment in the Syrian market, where earnings growth rates in the business sector and stock companies and cooperatives recorded a significant decline and the Syrian market started since 2001 is witnessing many cases of bankruptcy of private enterprises due to lower rates of return and slow sell products. And the number of industrial companies operating in Syria have almost halved since the study prepared by the Ministry of Industry for 2005 which confirmed the decline in the number of small and medium-sized industrial enterprises around $48 \%$ for the year 2000 and the reason for it to fall back on the size of the discharge and business bankruptcies witnessed by Syria during the period (2000- 2006) (Ministry of Industry-Syria, 2006: p5-6).

\section{Conclusions:}

\section{Conclusions and recommendations}

1. Economically model shows that financial policy played an important role in stimulating economic growth in Syria are greater than the monetary policy during the period studied, reaching regression coefficient between GDP and public expenditure 2.318 and it means that when public expenditures increase by one Syrian pound, it leads to an increase in the gross domestic product increased by 2,328 Syrian pounds. While the regression coefficient between GDP and money supply indicates that the increase in the money supply increased by one Syrian pounds and one leads to increased GDP by 0.732 Syrian pounds. In short, the regression coefficients show that economic activity affected during the period studied further using the public Expenditures of money supply control and the offer is apparently contrary to the concept that brought him many economic theories.

2. The model refers to the lack of moral appreciation coefficient for consumption in the period studied, which excludes the impact of consumer habits in determining the pattern of consumption, and this model do not appear 
any moral to private coefficient government expenditures and therefore the estimate mentioned model was unable to diagnose the private and government consumption expenditures relationship.

3. The model pointed to the existence of a strong relationship between private investment as the dependent variable and both private consumption and net transfers from the abroad world and the government's investment as independent variables, which means that the increase rate of the one Syrian pound and the one leading to increased private investment by 0.265 one Syrian pound private consumer expenditures and each additional pounds of remittances contribute to raising private investment increased by 9.9 Syrian pound., while the model showed the weakness of the relationship between public expenditures and government investment.

\section{Recommendations:}

1. The need to rationalize public expenditures and rearrange his priorities by achieving harmony between financial and monetary policy tools as part of the rules of corporate governance based on: (accountability), (transparency), (disclosure).

2. Development finance public expenditures sources (general revenue) all tax and non-tax types.

3. Follow-up public bodies and ministries strict follow-up, to do a full-earmarked funds to spend in the investment budget items, so as to increase the creation of public goods and the implementation of projects in a timely manner in order to avoid increasing the cost and price rises on the one hand and the loss of profit opportunities as a result of operating the delay from the point of another.

\section{References}

[1]. Ahmed Hashish, Adel (1982), "the economics of public finance," university culture, Egypt

[2]. Poddar, A. K. and Hunking, N. J .; OP. Cite

[3]. Nejmeh, Elias (2003), "Financial policy in Syria," Economic Journal, No. / 116 / October 2003

[4]. $\quad$ Ackley G .: "Macroeconomics: Theory and Policy," Macmillan publishing Co., Inc., New York, 1978

[5]. Pindyck, Robert S. \& Rubinfeld, Daniel L. (1998), "Economic Models and Economic Forecasts," McGraw-Hill International Editions, Economic Series. Forth Ed.

[6]. Gerson, Philip (1998); "The Impact of Financial Policy Variables on Output Growth." WP / 98/1, International Monetary Fund.

[7]. CeReau, G. "Public Expenditure and Decisions on Private Consumption," Public Finance Review, No. 3, Vol. XXXVII, 1982.

[8]. $\quad$ Carlstorm T .; Charles and Furest S., Timothy (1999), "Money Growth and Inflation: Does Financial Policy Matter?"; Federal Reserve Bank of Cleveland, April 15, 1999.

[9]. Musgrave, Richard A. and Musgrave, Peggy B. (1989); "Public Finance in Theory and Practice;" McGraw-HILL International Edition. Fifth Edition.

[10]. Gerson, Philip (1998); "The Impact of Financial Policy Variables on Output Growth." WP / 98/1, International Monetary Fund.

[11]. Nallari, Raj (2006); "Fridays Academy: Financial Policy and its impact," Griffith's lecture notes, World Bank Blogs, 07/07/2006.

[12]. http://pgpblog.worldbank.org/categories/fridays_academy [Accessed 20/12/2007].

[13]. Kannan, Ali (2002), "the recession in Syria," a paper presented to a symposium Tuesday Economic 2002, Economic Science Association.

[14]. Population Division of the Department of Economic and Social Affairs of the United Nations Secretariat, World Population Prospects: The 2006 Revision and World Urbanization Prospects: The 2005 Revision, http://esa.un.org/unpp, 2008.

[15]. Sturm, Michael and Gurtner, François (2007), "Financial Policy in Mediterranean Countries Developments, Structures and Implications for Monetary Policy"

[16]. the study of the reality of the industrial companies in Syria in the Syrian provinces of the 2006 Private Sector Directorate of the Ministry of Industry Damascus in 2006.

[17]. Statistical Brochures (2000-2011), the Central Bureau of Statistics, the Council of Ministers, the Syrian Arab Republic

[18]. Quarterly Statistical(2000-2011), the Central Bank of Syria.

[19]. http://www.amf.org.ae/amf/website/pages/page.aspx ?Type=8\&ID=549\&forceLanguage=ar 